\title{
Learning Strategies and Academic Goals to Strengthen Competencies in Electronics and Digital Circuits in Engineering Students
}

\author{
Maritza Cabana-Caceres ${ }^{1, *}$, Cristian Castro-Vargas ${ }^{1}$, Laberiano Andrade-Arenas ${ }^{1}$, Monica Romero-Valencia ${ }^{1}$, Haydee Castro-Vargas ${ }^{2}$ \\ ${ }^{1}$ Faculty of Sciences and Engineering, Universidad de Ciencias y Humanidades, Lima, 27, Peru \\ ${ }^{2}$ Faculty of Psychology, Federico Villareal National University, Lima, 15082, Peru
}

\section{ITEM INFORMATION}

Article history:

Received: 06 October, 2020

Accepted: 21 December, 2020

Online: 10 January, 2021

Keywords:

Learning strategies

Academic goals

Competencies

Electronics

\begin{abstract}
SUMMARY
The purpose of this article was to determine the incidence between learning strategies and academic goals in the competences of the curricular experience of electronics and digital circuits in engineering students of a private university in Lima, Peru. The objective was to explain how learning strategies and academic goals explain the behavior of engineering students of competencies in electronics and digital circuits. For this study, a sample of 89 students from the III cycle was used, to whom the ACRA test instruments were applied for the learning strategies of Román and Gallego (2001), the CMA academic goals test of Durán and Arias (2015) and a test to assess skills in electronics and digital circuits. According to the results obtained, it was shown that learning strategies and academic goals affect the skills of electronics and digital circuits in engineering students. By obtaining $x 2$ $=83.782,(p=.000<0.05$ and Wald $=16.326$ showing that the proposed model is acceptable
\end{abstract}

\section{Introduction}

With globalization and the increasing ease of obtaining information, in Peru in most higher education institutions there is still a large gap in how to carry out an adequate learning strategy despite having the information at hand, regulatory bodies such as the National Superintendency of Higher Education SUNEDU [1] and the accreditation of the System of Evaluation, Accreditation and Certification of Educational Quality SINEACE [2] concerned about this, they try to implement norms so that educational institutions comply with basic quality standards, in this context, university education is in a process of educational reform to a model based on competencies, which they find it difficult to implement while maintaining the traditional teaching [3].

Thus at the national level, although access to university education and the level of skills as indicated is improving, there are still low levels of quality standards also at the international level, reflecting students with weak skills, low performance and insertion problems and job retention [4]. Several universities are still in the process of licensing and accreditation, so they are carrying out their curricular restructuring, to achieve a coherent curriculum to the institutional educational model, in an integrated manner according to the socio-economic, political, cultural "Corresponding Author: Maritza Cabana-Caceres, Email: mcabana@uch.edu.pe www.astesj.com

https://dx.doi.org/10.25046/aj060110 context, in the local scope. framework, regional and global [5]. In this sense, a student who does not exercise his skills acquired in the workplace becomes a stranger to his specialty, unable to continue developing his skills [6].

This situation is aggravated, because engineering careers require strong ICT skills, not only for students but also for teachers [7] who, when developing their classes with a curricular program that does not include ICT due to lack of training in the teaching staff and the low implementation of devices and laboratory equipment, it becomes a challenge [8]. In this sense, in a private university of Lima, in the course of electronics and digital circuits of the engineering faculty, passive students were observed in the development of the required competences, presenting deficiencies in the disciplinary knowledge of electronics and digital circuits, having fragmented learning. and not integrated into their professional training, losing interest in the subject, consequently, not being able to solve specialty problems when carrying out their pre-professional and / or work practices, which prevents them from successfully facing the demands of a dynamic real world. In this sense, it shows the need to implement and apply learning strategies and academic goals that address the indicated weaknesses, aimed at seeking the development of effective skills in electronics and digital circuits and in future engineering students that allows them 
to exercise in a integrated. the significant learning acquired during their academic training stage at the university.

The need to implement and apply learning strategies and academic goals that address the identified weaknesses is shown, aimed at seeking the development of effective skills in electronics and digital circuits and in future engineering students that allows them to exercise in an integrated manner. The significant learning acquired during their academic training stage at the university.

For example, in Chile, it was found that learning goals and the attribution of academic success to effort have higher statistics. highlighted with respect to academic performance, this allows identifying and considering these dimensions in student support programs to promote academic achievement [9].

Also in Colombia, they obtained the existence of positive and significant correlations in study habits, learning strategies and academic performance, where the importance of using learning strategies as study habits to promote academic performance was highlighted, so both recommended creating intervention and support programs for strengthening in these areas [10].

The students from the Universidad Privada del Norte, Lima, were analyzed with a survey on the use of Arduino technology and a competency learning test. The research resulted in a significant correlation with a Spearman coefficient equal to 0.702 and a $p$ value of 0.01 , showing that the use of Arduino technology improves the development of students' skills in their learning [11].

Thus, in another private university of Lima, 96 students from the Faculty of Engineering were applied the instruments of the CMA Academic Goals questionnaire and Form 5 of Self-concept, determining from the results an $\mathrm{r}(96)=.205, \mathrm{p}=.046$ of the variables, with which it can be said that there is a relationship weak and significant positive between academic goals and self-concept, which means that high goals will be weakly related to high selfconcept [12].

On the other hand, in a study of 290 students from the National University of San Marcos, it allowed to clarify the association between the learning strategies variables, motivation in relation to the explained variable of the study to predict the application of certain learning strategies, cognitive and metacognitive factors in students as indicators and decisive determinants to achieve reading comprehension [13].

The variables that we propose to study are expressed, the first study variable being learning strategies, there are different definitions, stating that it is a metacognitive, planned and conscious process of the subject in a given situation, influenced by the individual's perceptions to achieve optimal learning [14]. Given the above, it is reinforced that the strategies adopted by the students are sequentially concatenated and deliberately planned, in order to achieve the learning of the required task [15]. It can also be said that it is a process of sequence of decisions of the subject in a conscious and intentional state, in which the student deliberately decides and recovers knowledge, which requires the performance of a certain activity [16].

Another variable of study is the variable academic goals that is defined as the purposes proposed by the students, which guide their intentions and actions to obtain their achievements before certain academic activities using the necessary resources. Likewise, it is indicated that they are the objectives that students want to achieve through planning, which will be their action to have a better understanding according to the complexity of the goal, for the solution of the academic activities to be developed [17].

Likewise, they are an integrated and organized pattern of thoughts and reasons that a management produces for a context of achievement, which includes the thoughts of competence, success, competitiveness, effort, errors and evaluation of its objectives to be fulfilled in the classroom [18] .

The last variable of studies competences of electronic and digital circuits, according to the Electronic Engineering curriculum with a major in Telecommunications of the Private University of Lima [19], mentions that the competences are the set of related knowledge, skills, attitudes and values with each other, in an integral way, that the student develops in the university to perform in academic activities and professional practice, in accordance with the standards of their specialty under the social, political, economic and labor context that governs it.

Posing the problem general research which is: What incidence exists between the learning strategies and the academic goals in the electronic and digital circuits competences in a Private University Lima, 2020? Regarding the specific problems, the following are established:

(a) What impact do the learning strategies and academic goals have on basic electronics and digital circuits in a Private University Lima, 2020? (b) What impact do the learning strategies and academic goals have on the electrical components of electronic and digital circuits in a Private University Lima, 2020? (c) What impact do the learning strategies and academic goals have on the hardware and digital circuits of the arduino electronics at the Universidad Privada Lima, 2020? (d) What impact do learning strategies and academic goals have on arduino electronics and digital circuits software at a Private University Lima, 2020?

For its part, the general objective set for this research is to determine the incidence between learning strategies and academic goals in the competencies of the subject of electronics and circuits in a private university Lima, Peru, and its specific objectives that are considered for the present investigation are: (a) establish the relationship between learning strategies and academic goals in basic electronics and digital circuits in a Private University Lima, 2020 (b) establish the relationship between learning strategies and academic goals in electrical components of electronics and digital circuits in a Private University of Lima, 2020 (c) establish the relationship between learning strategies and academic goals in arduino electronic hardware and digital circuits in a Private University of Lima, 2020 (d) establish the relationship between learning strategies and academic goals in arduino electronics and digital circuit software at a Private University Lima, 2020.

\section{Methodology}

The present investigation was of a quantitative approach because each stage proceeds to the next and the steps cannot be ignored, it is possible to define and limit them, in addition, it is known exactly where the problem begins, data collection was also carried out, to measure the variables learning strategies and skills 
of electronics and digital circuits in numerical expressions and were analyzed with statistical methods.

\subsection{Variables operationalization}

For the learning strategies, 119 questions were used (see appendix), on a Likert scale, with 5 dimensions and a total of 9 indicators (Table 1).

Table 1: Operationalization of variable learning strategies

\begin{tabular}{|c|c|c|c|c|}
\hline Dimensions & Indicators & Items & Scale & $\begin{array}{c}\text { Levels or } \\
\text { ranges }\end{array}$ \\
\hline \multirow{2}{*}{ 1. Acquisition } & $\begin{array}{l}\text { 1.1 Attentional } \\
\text { strategies }\end{array}$ & $1-10$ & \multirow{5}{*}{$\begin{array}{c}\text { A: } \\
\text { Never } \\
(1) \\
\text { B: } \\
\text { Sometim } \\
\text { es (2) }\end{array}$} & \multirow{5}{*}{$\begin{array}{c}\text { Low } \\
119-277 \\
\text { Moderate } \\
278-437\end{array}$} \\
\hline & $\begin{array}{c}1.2 \text { Repetition } \\
\text { strategies }\end{array}$ & $11-20$ & & \\
\hline \multirow{3}{*}{ 2.Codification } & $\begin{array}{c}2.1 \\
\text { Mnemonization } \\
\text { strategies }\end{array}$ & $21-42$ & & \\
\hline & $\begin{array}{l}2.2 \text { Processing } \\
\text { strategies }\end{array}$ & $43-63$ & & \\
\hline & $\begin{array}{c}2.3 \text { Organizational } \\
\text { strategies }\end{array}$ & $64-66$ & & \\
\hline \multirow[b]{2}{*}{ 3.recovery } & $\begin{array}{c}\text { 3.1 Search } \\
\text { strategies }\end{array}$ & $67-75$ & \multirow{4}{*}{$\begin{array}{c}\text { C: Many } \\
\text { times (3) } \\
\text { D: } \\
\text { Always } \\
\text { (4) }\end{array}$} & \\
\hline & $\begin{array}{c}\text { 3.2 Response } \\
\text { generation } \\
\text { strategies }\end{array}$ & $76-84$ & & $438-595$ \\
\hline \multirow{2}{*}{ 4.Support } & $\begin{array}{l}\text { 4.1 Metacognitive } \\
\text { strategies }\end{array}$ & $85-101$ & & \\
\hline & $\begin{array}{c}4.2 \text { Socio- } \\
\text { affective strategies }\end{array}$ & $102-119$ & & \\
\hline
\end{tabular}

Regarding academic goals, 16 questions were used, on a Likert scale, with 3 dimensions and a total of 8 indicators (Table 2). And for the electronic and digital circuits competences, 20 questions were measured, on a dichotomous scale, with 4 dimensions and 12 indicators in total (Table 3).

Table 2: Operationalization of the variable academic goals

\begin{tabular}{|c|c|c|c|c|}
\hline Dimensions & Indicators & Items & Scale & $\begin{array}{c}\text { Levels } \\
\text { or } \\
\text { ranges }\end{array}$ \\
\hline \multirow{2}{*}{$\begin{array}{c}1 . \\
\text { Learning } \\
\text { objectives }\end{array}$} & $\begin{array}{c}\text { 1.1. Problem } \\
\text { solving }\end{array}$ & $1-3$ & \multirow{8}{*}{$\begin{array}{c}1: \\
\text { Strongly } \\
\text { disagree } \\
2: \\
\text { disagree } \\
3: \\
\text { Neither } \\
\text { agree } \\
\text { nor } \\
\text { disagree } \\
4: \text { agree } \\
5: \\
\text { Strongly } \\
\text { agree }\end{array}$} & \multirow{8}{*}{$\begin{array}{c}\text { Low } \\
16-37 \\
\text { Moderat } \\
\mathrm{e} \\
38-59 \\
\text { High } \\
60-80\end{array}$} \\
\hline & $\begin{array}{c}\text { 1.2. Progressive } \\
\text { learning }\end{array}$ & $4-7$ & & \\
\hline \multirow{3}{*}{$\begin{array}{c}2 . \\
\text { Achieveme } \\
\text { nt } \\
\text { objectives }\end{array}$} & $\begin{array}{c}\text { 2.1. Academic } \\
\text { achievement }\end{array}$ & $8-9$ & & \\
\hline & $\begin{array}{l}\text { 2.2. Professional } \\
\text { achievement }\end{array}$ & 10 & & \\
\hline & $\begin{array}{l}\text { 2.3. Personal } \\
\text { achievement }\end{array}$ & 11 & & \\
\hline \multirow{3}{*}{$\begin{array}{l}\text { 3.Objectiv } \\
\text { es of social } \\
\text { reinforcem } \\
\text { ent }\end{array}$} & $\begin{array}{l}\text { 3.1. Social } \\
\text { recognition }\end{array}$ & $\begin{array}{l}12 \\
14\end{array}$ & & \\
\hline & $\begin{array}{l}\text { 3.2. Classroom } \\
\text { stimulation }\end{array}$ & $\begin{array}{l}13 \\
16\end{array}$ & & \\
\hline & $\begin{array}{l}\text { 3.3. Superior } \\
\text { approval }\end{array}$ & 15 & & \\
\hline
\end{tabular}

\subsection{Population}

A census population, composed of 89 students, from the third cycle of the engineering faculty of the University of Sciences and Humanities, 2020- I was studied.
2.3. Techniques, data collection instruments, validity and reliability

The instruments of the Roman and Gallegos Acra Test (see appendix) were applied to the students to evaluate the learning strategies, as well as the CMA questionnaire of Durán (2015) to evaluate their academic goals and finally a test was carried out to measure the competencies of electronics and digital circuits. The information collected was then transferred to a database in Excel and to the statistical program SPSS version 23, which will allow us to perform the data analysis.

Table 3: Operationalization of the variable competencies of electronic and digital circuits

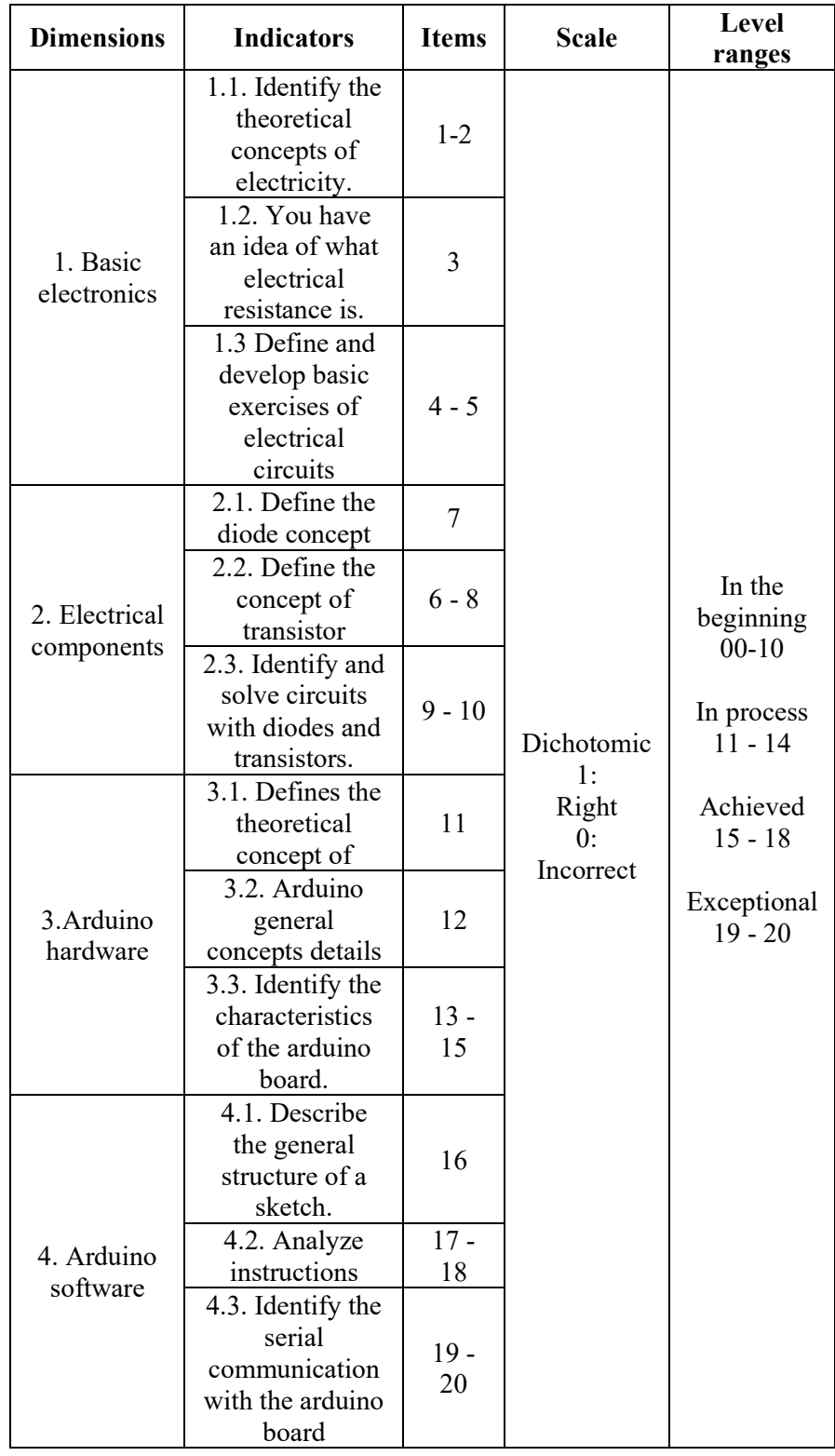

The educational data mining technique is a tool that also allows data collection and analysis for subsequent decision-making, which is also suitable for evaluating groups of students, with the advantage of being able to cover a large number of data, as is the case of this investigation that has 119 questions for the study, for the case of the present investigation the data will be analyzed using SPSS. 
Regarding the validation of the instruments, the content validity of the expert judgment was carried out and for the reliability a pilot test of a sample of 20 students of the electronics and digital circuits subject was used, the statistical values verified the reliability of instruments (Table 4).

Table 4: Reliability of the instrument

\begin{tabular}{|c|c|c|c|}
\hline Variables & $\begin{array}{c}\text { Statistics } \\
\text { Reliability }\end{array}$ & Value & $\begin{array}{c}\text { No. of } \\
\text { lements }\end{array}$ \\
\hline $\begin{array}{c}\text { Learning } \\
\text { strategies }\end{array}$ & $\begin{array}{c}\text { Cronbach's } \\
\text { alpha }\end{array}$ & 0.857 & 119 \\
\hline Academic goals & $\begin{array}{c}\text { Cronbach's } \\
\text { alpha }\end{array}$ & 0.851 & 16 \\
\hline $\begin{array}{c}\text { Competences in } \\
\text { electronics and } \\
\text { digital circuits }\end{array}$ & $\begin{array}{c}\text { Kuder- } \\
\text { Richardson }\end{array}$ & 0.8179 & 20 \\
\hline
\end{tabular}

\section{Results}

The results obtained from the study are shown below.

\subsection{Description of the learning strategies variable}

Define abbreviations and acronyms the first time they are used in the text, even after they have been defined in the abstract. Do not use abbreviations in the title or headings unless they are unavoidable.

Table 5: Levels of variable learning strategies

\begin{tabular}{|l|l|l|l|}
\hline & & Frequency & Percentage \\
\hline Valid & Low & 26 & 29.3 \\
\cline { 2 - 4 } & Moderate & 48 & 53.9 \\
\cline { 2 - 4 } & High & 15 & 16.8 \\
\cline { 2 - 4 } & Total & 89 & 100 \\
\hline
\end{tabular}

Learning strategies

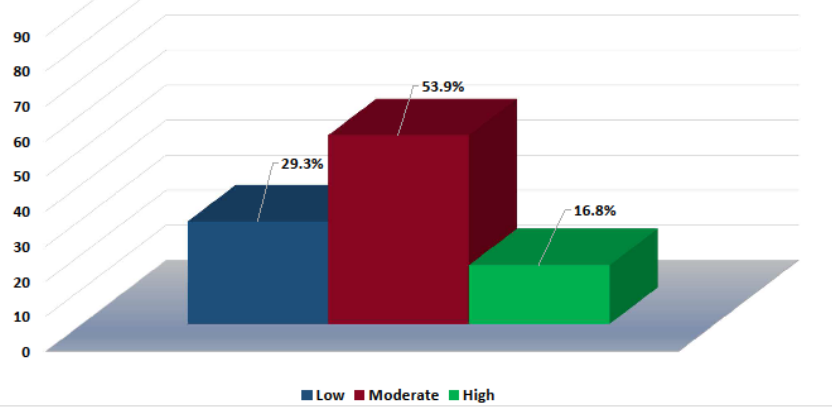

Figure 1: Levels of the learning strategies variable

Table 5 and Figure 1 show the percentage values of the learning strategies variable, of a total of 89 students. With the results obtained, it can be seen that the learning strategies tend to be moderate with $53.9 \%$.

Table 6: Levels of dimensions of learning strategies

\begin{tabular}{|l|l|l|l|l|l|}
\hline & & Low & Moderate & $\begin{array}{r}\text { Hig } \\
\mathbf{h}\end{array}$ & \multicolumn{1}{|c|}{ Total } \\
\hline Acquisition & Frequency & 15 & 54 & 20 & 89 \\
\cline { 2 - 6 } & Percentage & 16.8 & 60.7 & 22.5 & 100 \\
\hline Coding & Frequency & 13 & 59 & 17 & 89 \\
\hline
\end{tabular}

\begin{tabular}{|l|l|l|l|l|l|}
\hline & Percentage & 14.6 & 66.3 & 19.1 & 100 \\
\hline \multirow{3}{*}{ Recovery } & Frequency & 16 & 53 & 20 & 89 \\
\cline { 2 - 6 } & Percentage & 17.9 & 59.6 & 22.5 & 100 \\
\hline \multirow{3}{*}{ Support for } & Frequency & 18 & 49 & 22 & 89 \\
\cline { 2 - 6 } & Percentage & 20.2 & 55.1 & 24.7 & 100 \\
\hline
\end{tabular}

\subsection{Description of the dimensions of the learning strategies}

Table 6 and figure 2 show the percentage values of the dimensions of the learning strategies, of a total of 89 students. From these results, it is estimated that the support dimension with more than $24 \%$ presents the best results compared to the other dimensions.

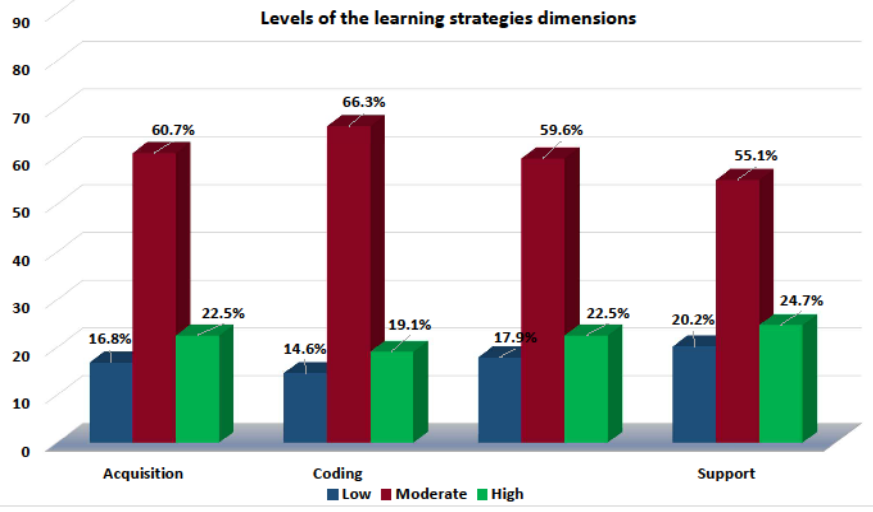

Figure 2: Levels of the dimensions of learning strategies

\subsection{Description of variable academic goals}

Table 7 and Figure 3 show the percentage values of the variable academic goals, of a total of 89 students. With the results obtained, it can be seen that the level of perception of academic goals has a trend of moderate level with more than $60 \%$.

Table 7: Levels of variable academic goals

\begin{tabular}{|l|l|l|l|}
\hline & & Frequency & Percentage \\
\hline Valid & Low & 12 & 13.5 \\
\cline { 2 - 4 } & Moderate & 55 & 61.8 \\
\cline { 2 - 4 } & High & 22 & 24.7 \\
\cline { 2 - 4 } & Total & 89 & 100 \\
\hline
\end{tabular}

Academic goals

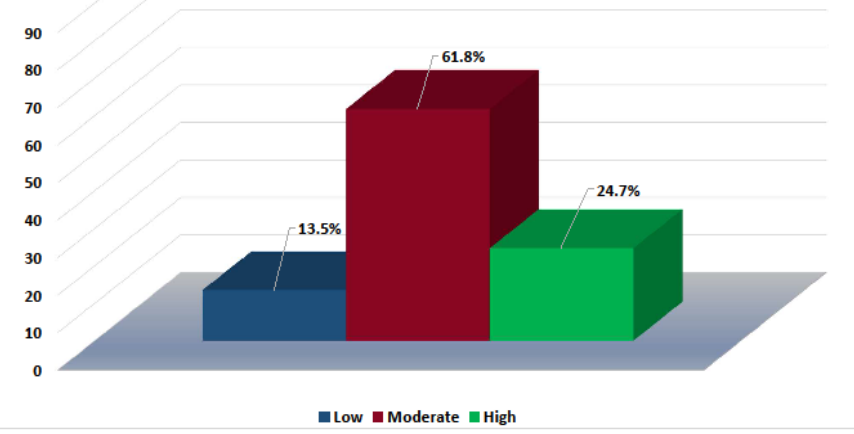

Figure 3: Levels of the academic goals variable 


\subsection{Description of the dimensions of the academic goals}

Table 8 and Figure 4 show the percentage values of the academic goals dimension of a total of 89 students. Based on these results, it is estimated that the achievement goals dimension presents better results with more than $30 \%$ compared to the other dimensions.

Table 8: Levels of the dimensions of academic goals

\begin{tabular}{|l|l|l|l|l|l|}
\hline & & Low & Moderate & High & Total \\
\hline \multirow{2}{*}{$\begin{array}{l}\text { Learning } \\
\text { goals }\end{array}$} & Frequency & fifteen & 46 & 28 & 89 \\
\cline { 2 - 6 } & Percentage & 16.8 & 51.7 & 31.5 & 100 \\
\hline $\begin{array}{l}\text { Achievement } \\
\text { goals }\end{array}$ & Frequency & 10 & 48 & 31 & 89 \\
\cline { 2 - 6 } & Percentage & 11.3 & 53.9 & 34.8 & 100 \\
\hline $\begin{array}{l}\text { Objectives of } \\
\text { social } \\
\text { reinforcement }\end{array}$ & Frequency & 15 & 45 & 29 & 89 \\
\cline { 2 - 6 } & Percentage & 16.7 & 50.7 & 32.6 & 100 \\
\hline
\end{tabular}

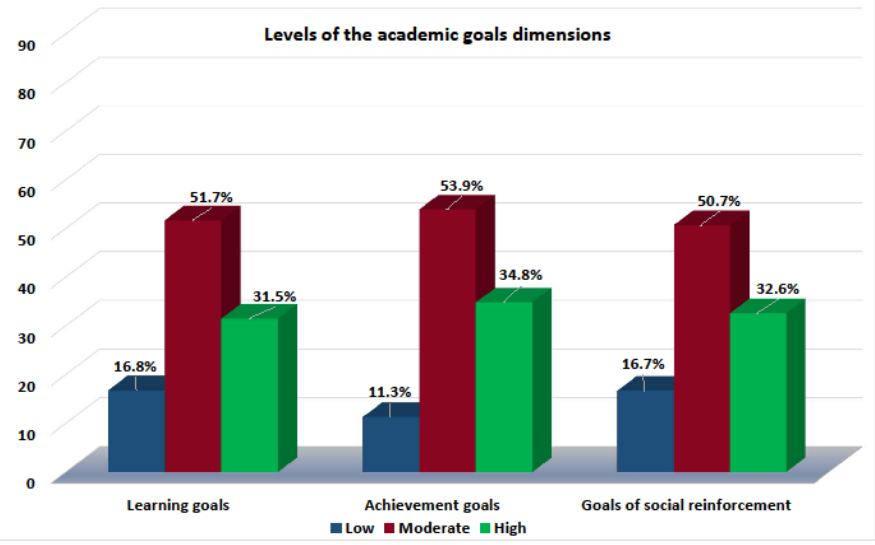

Figure 4: Levels of the academic goals dimensions

\subsection{Description of the electronic and digital circuits skills variable}

Table 9 and Figure 5 show the percentage values of the variable dimensions of electronics and digital circuits, of a total of 89 students, which shows a trend of students at the level reached with less than $70 \%$.

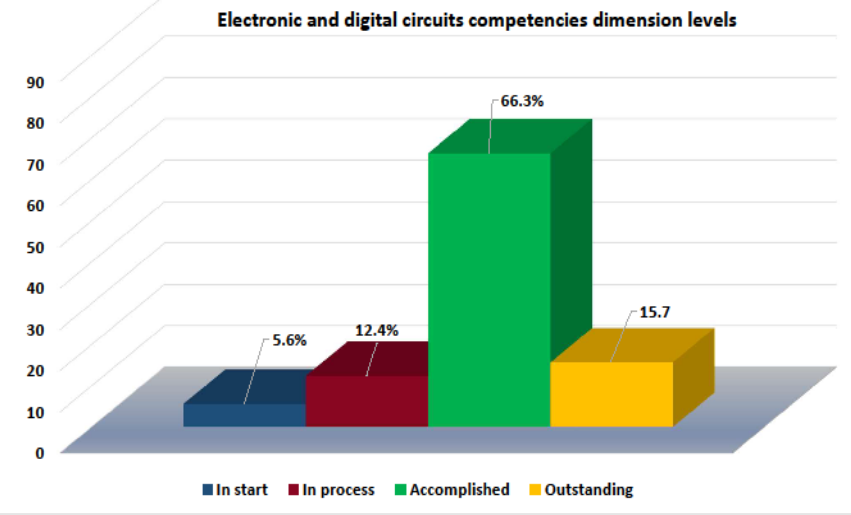

Figure 5: Dimension levels of electronic and digital circuits competencies
Table 9: Levels of electronic and digital circuits variable competencies

\begin{tabular}{|l|l|l|l|}
\hline & & Frequency & Percentage \\
\hline Valid & $\begin{array}{l}\text { In the } \\
\text { beginning }\end{array}$ & 5 & 5.6 \\
\cline { 2 - 4 } & In process & 11 & 12.4 \\
\cline { 2 - 4 } & Accomplished & 59 & 66.3 \\
\cline { 2 - 4 } & Exceptional & 14 & 15.7 \\
\cline { 2 - 4 } & Total & 89 & 100 \\
\hline
\end{tabular}

\subsection{Description of the competencies dimensions of electronics} and digital circuits

Table 10 and Figure 6 show the percentage values of the dimensions of competencies in electronics and digital circuits, of a total of 89 students. From these results, it is estimated that the arduino software dimension has low outstanding results with less than $12 \%$ compared to the other dimensions.

Table 10: Dimensional Competency Levels for Electronic and Digital Circuits

\begin{tabular}{|l|l|l|l|l|l|l|}
\hline & & Initial & $\begin{array}{l}\text { In } \\
\text { process }\end{array}$ & $\begin{array}{l}\text { Accompli } \\
\text { shed }\end{array}$ & $\begin{array}{l}\text { In } \\
\text { outgoin } \\
\text { g }\end{array}$ & Total \\
\hline $\begin{array}{l}\text { Basic } \\
\text { electronic }\end{array}$ & $\begin{array}{l}\text { Frequ } \\
\text { ency }\end{array}$ & 1 & 5 & 67 & 16 & 89 \\
\cline { 2 - 7 } & $\begin{array}{l}\text { Percen } \\
\text { tage }\end{array}$ & 1.1 & 5.6 & 75.3 & 18.0 & 100 \\
\hline $\begin{array}{l}\text { Electric } \\
\text { components }\end{array}$ & $\begin{array}{l}\text { Frequ } \\
\text { ency }\end{array}$ & 3 & 9 & 65 & 12 & 89 \\
\cline { 2 - 7 } & $\begin{array}{l}\text { Percen } \\
\text { tage }\end{array}$ & 3.4 & 10.1 & 73.0 & 13.5 & 100 \\
\hline $\begin{array}{l}\text { Arduino } \\
\text { Hardware }\end{array}$ & $\begin{array}{l}\text { Frequ } \\
\text { ency }\end{array}$ & 5 & 11 & 60 & 13 & 89 \\
\cline { 2 - 7 } & $\begin{array}{l}\text { Percen } \\
\text { tage }\end{array}$ & 5.6 & 12.4 & 67.4 & 14.6 & 100 \\
\hline $\begin{array}{l}\text { Arduino } \\
\text { software }\end{array}$ & $\begin{array}{l}\text { Frequ } \\
\text { ency }\end{array}$ & 8 & 14 & 57 & 10 & 89 \\
\cline { 2 - 7 } & $\begin{array}{l}\text { Percen } \\
\text { tage }\end{array}$ & 9.0 & 15.7 & 64.0 & 11.3 & 100 \\
\hline
\end{tabular}

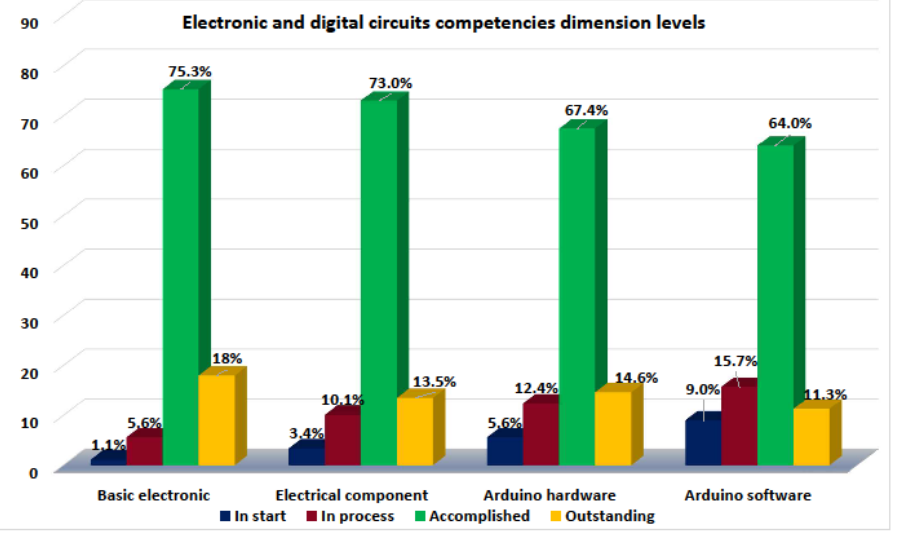

Figure 6: Dimension levels of electronic and digital circuits competencies

\subsection{Contrast of the general hypothesis}

Ho: There is no incidence between learning strategies and academic goals in electronic skills and digital circuits in a Private University Lima, 2020. 
HG: There is an incidence between learning strategies and academic goals in electronic skills and digital circuits in a Private University Lima, 2020.

Table 11: Model fit and likelihood ratio tests for the general hypothesis

\begin{tabular}{|l|r|r|r|r|}
\hline \multicolumn{5}{|c|}{ Model fit information } \\
\hline Model & $\begin{array}{r}\text { Logarithm of probability - } \\
\mathbf{2}\end{array}$ & $\begin{array}{r}\text { Chi } \\
\text { squared }\end{array}$ & gl & S.I.G \\
\hline $\begin{array}{l}\text { Interception } \\
\text { only }\end{array}$ & 286,034 & & & \\
\hline Final & 202,251 & 83,782 & 36 &, 000 \\
\hline
\end{tabular}

Table 11 shows that the value $\mathrm{x} 2=83.782,(\mathrm{p}=.000<0.05)$, indicates that the proposed model is acceptable. In this sense, the null hypothesis is rejected, with a probability of error less than $5 \%$.

Table 12: Pseudo R squared of general hypothesis

\begin{tabular}{|l|r|}
\hline \multicolumn{2}{|c|}{ Pseudo R squared } \\
\hline Cox and Snell &, 610 \\
\hline Nagelkerke &, 630 \\
\hline McFadden &, 272 \\
\hline
\end{tabular}

Table 13: Parameter estimates of the general hypothesis

\begin{tabular}{|l|r|r|r|r|r|}
\hline & & & & \multicolumn{2}{c|}{$\begin{array}{c}\text { 95\% } \\
\text { interval } \\
\text { trustworthy }\end{array}$} \\
\cline { 4 - 6 } & Estimate & S.I.G & Wald & \multicolumn{1}{c|}{ Min } & \multicolumn{1}{c|}{ Max } \\
\hline $\begin{array}{l}\text { [V3_Competences of } \\
\text { electronics and digital } \\
\text { circuits = 1] }\end{array}$ & $-9,224$ &, 000 & 25,904 & $-12,776$ & $-5,672$ \\
\hline $\begin{array}{l}\text { [V3_Competencies of } \\
\text { electronics and digital } \\
\text { circuits = 2] }\end{array}$ & $-7,549$ &, 000 & 24,350 & $-10,547$ & $-4,550$ \\
\hline $\begin{array}{l}\text { [V1_Learning strategies } \\
\text { 1] }\end{array}$ & $-9,918$ &, 000 & 16,326 & $-14,728$ & -5.107 \\
\hline $\begin{array}{l}\text { [V1_Learning strategies }= \\
\text { 2] }\end{array}$ & $-4,936$ &, 001 & 11,346 & $-7,808$ & $-2,064$ \\
\hline [V2_Academic Goals $=1]$ & $-3,348$ & .014 & 6,053 & $-6,016$ & -.681 \\
\hline [V2_Academic Goals = 2] & $-2,624$ & .038 & 4,311 & -5.101 & -.147 \\
\hline
\end{tabular}

Table 12 presents favorable values of pseudo $\mathrm{R}$ squared, which ensures a fit adequate of the proposed model to explain competencies in electronics and digital circuits. Similarly, it is stated that learning strategies is the variable that affects the most, since it presents a value of Wald $=16.326$ and $\mathrm{p}=.000<0.05$ (Table 13).

\subsection{Specific hypothesis test 1}

Ho: There is no incidence between the learning strategies and the academic goals in the basic electronics of electronics and digital circuits in a Private University Lima, 2020.

$\mathrm{H} 1$ : There is an incidence between the learning strategies and the academic goals in the basic electronics of electronics and digital circuits in a Private University Lima, 2020.

Table 14 shows that the value $\mathrm{x} 2=61.281,(\mathrm{p}=.005<0.05)$, indicates that the proposed model is acceptable. In this sense, the null hypothesis is rejected with a probability of error less than $5 \%$.
Table 14: Model fit and likelihood ratio tests for specific hypothesis 1

\begin{tabular}{|l|l|l|c|l|}
\hline \multicolumn{5}{|c|}{ Model fit information } \\
\hline \multicolumn{1}{|c|}{ Model } & $\begin{array}{c}\text { Logarithm of probability - } \\
\mathbf{2}\end{array}$ & $\begin{array}{c}\text { Chi } \\
\text { squared }\end{array}$ & gl & S.I.G \\
\hline $\begin{array}{l}\text { Interception } \\
\text { only }\end{array}$ & 182,351 & & & \\
\hline Final & 121,070 & 61,281 & 36 &, 005 \\
\hline
\end{tabular}

Table 15: Pseudo R squared for specific hypothesis 1

\begin{tabular}{|l|r|}
\hline \multicolumn{2}{|c|}{ Pseudo R squared } \\
\hline Cox and Snell &, 498 \\
\hline Nagelkerke &, 557 \\
\hline McFadden &, 307 \\
\hline
\end{tabular}

Table 15 presents favorable pseudo $\mathrm{R}$ squared values, which ensures an adequate fit of the proposed model to explain skills in electronics and digital circuits.

Likewise, learning strategies is the variable that most affects basic electronics of the explained variable with a value of Wald $=$ 21.485 and $\mathrm{p}=.000<0.05$ (Table 16).

Table 16: Parameter estimates for general hypothesis 1

\begin{tabular}{|l|r|r|r|r|r|}
\hline & & & & \multicolumn{2}{c|}{$\begin{array}{c}\text { 95\% } \\
\text { interval } \\
\text { trustworthy }\end{array}$} \\
\cline { 4 - 6 } & Estimate & S.I.G & Wald & \multicolumn{1}{c|}{ Min } & Max \\
\hline $\begin{array}{l}\text { [V3D1_basic electronics } \\
\text { of electronics and digital } \\
\text { circuits=1] }\end{array}$ & $-5,632$ &, 000 & 29,959 & $-9,130$ & $-2,134$ \\
\hline $\begin{array}{l}\text { [V3D1_basic electronics } \\
\text { of electronics and digital } \\
\text { circuits=2] }\end{array}$ & $-5,268$ &, 003 & 23,538 & $-10,116$ &,- 421 \\
\hline $\begin{array}{l}\text { [V1_Learning } \\
\text { strategies=1] }\end{array}$ & $-2,931$ &, 000 & 21,485 & $-6,007$ &, 146 \\
\hline $\begin{array}{l}\text { [V1_Learning } \\
\text { strategies=2] }\end{array}$ & $-2,356$ & .014 & 10,547 & $-6,069$ & 1,356 \\
\hline [V2_Academic goals=1] & $-1,659$ &, 004 & 18,217 & $-4,606$ & 1,289 \\
\hline [V2_Academic goals=2] & 1,415 &, 005 & 16,788 & $-1,710$ & 4,539 \\
\hline
\end{tabular}

Table 15 presents favorable pseudo $\mathrm{R}$ squared values, which ensures an adequate fit of the proposed model to explain skills in electronics and digital circuits.

Likewise, learning strategies is the variable that most affects basic electronics of the explained variable with a value of Wald $=$ 21.485 and $\mathrm{p}=.000<0.05$ (Table 16).

\subsection{Specific hypothesis test 2}

Ho: There is no incidence between the learning strategies and the academic goals in the electrical components of electronics and digital circuits in a Private University Lima, 2020.

$\mathrm{H} 2$ : There is an incidence between the learning strategies and the academic goals in the electrical components of electronics and digital circuits in a Private University Lima, 2020. 
Table 17: Model fit tests and likelihood ratio for specific hypothesis 2

\begin{tabular}{|l|c|r|r|r|}
\hline \multicolumn{5}{|c|}{ Model fit information } \\
\hline Model & $\begin{array}{l}\text { Logarithm of } \\
\text { probability -2 }\end{array}$ & $\begin{array}{r}\text { Chi } \\
\text { squared }\end{array}$ & gl & S.I.G \\
\hline $\begin{array}{l}\text { Interception } \\
\text { only }\end{array}$ & 180,100 & & & \\
\hline Final & 126,963 & 53,136 & 36 & .033 \\
\hline
\end{tabular}

Table 17 shows that the value $\mathrm{x} 2=53.136,(\mathrm{p}=.033<0.05)$, indicates that the proposed model serves to explain the dependent behavior of the variable competencies of electronic and digital circuits with respect to electrical circuits. In this sense, the null hypothesis is rejected with a probability of error less than $5 \%$.

Table 18: Pseudo R squared for specific hypothesis 2

\begin{tabular}{|l|r|}
\hline \multicolumn{2}{|c|}{ Pseudo R squared } \\
\hline Cox and Snell &, 450 \\
\hline Nagelkerke &, 504 \\
\hline McFadden &, 269 \\
\hline
\end{tabular}

Table 18 presents favorable pseudo R squared values, which ensures an adequate fit of the proposed model to explain skills in electronics and digital circuits. Likewise, academic goals is the variable that most affects the electrical components of the explained variable with a value of Wald $=16.073$ and $p=.004$ $<0.05$ (Table 19).

Table 19: Parameter estimates for general hypothesis 2

\begin{tabular}{|l|r|r|r|r|r|}
\hline & & & & \multicolumn{2}{c|}{$\begin{array}{c}\mathbf{9 5 \%} \\
\text { interval } \\
\text { trustworthy }\end{array}$} \\
\cline { 4 - 6 } & Estimate & S.I.G & Wald & \multicolumn{1}{c|}{ Min } & Max \\
\hline $\begin{array}{l}\text { [V3D2_electrical } \\
\text { components of electronic } \\
\text { and digital circuits=1] }\end{array}$ & $-6,288$ &, 001 & 11,176 & $-9,974$ & $-2,601$ \\
\hline $\begin{array}{l}\text { [V3D2_electrical } \\
\text { components of electronic } \\
\text { and digital circuits=1] }\end{array}$ & $-3,936$ &, 001 & 16,531 & $-6,955$ &,- 917 \\
\hline $\begin{array}{l}\text { [V1_Learning } \\
\text { strategies=1] }\end{array}$ & $-5,317$ & .020 & 14,725 & $-10,111$ &,- 523 \\
\hline $\begin{array}{l}\text { [V1_Learning } \\
\text { stra-egies=2] }\end{array}$ & $-2,856$ &, 051 & 8,371 & $-7,635$ & 1,924 \\
\hline $\begin{array}{l}\text { [V2_Academic goals_ }= \\
\text { 1] }\end{array}$ & $-2,151$ & .042 & 9,985 & $-5,143$ &, 841 \\
\hline [V2_Academic goals=2] & $-3,130$ &, 004 & 16,073 & $-5,620$ & -.641 \\
\hline
\end{tabular}

\subsection{Specific hypothesis test 3}

Ho: There is no incidence between learning strategies and academic goals in arduino electronics hardware and digital circuits in a Private University Lima, 2020.

H3: There is an incidence between learning strategies and academic goals in arduino electronics hardware and digital circuits in a Private University Lima, 2020.

Table 20: Model fit and likelihood ratio tests for specific hypothesis 3

\begin{tabular}{|l|l|r|r|r|}
\hline \multicolumn{5}{|c|}{ Model fit information } \\
\hline Model & $\begin{array}{l}\text { Logarithm of } \\
\text { probability -2 }\end{array}$ & $\begin{array}{r}\text { Chi } \\
\text { squared }\end{array}$ & gl & S.I.G \\
\hline
\end{tabular}

\begin{tabular}{|l|r|r|r|r|}
\hline $\begin{array}{l}\text { Interception } \\
\text { only }\end{array}$ & 170,545 & & & \\
\hline Final & 79,648 & 90,897 & 36 &, 000 \\
\hline
\end{tabular}

Table 20 shows that the value $\mathrm{x} 2=90.897,(\mathrm{p}=.033<0.05)$, indicates that the proposed model serves to explain the dependent behavior of the competence variable of the electronic and digital circuit with respect to the Arduino hardware. In this sense, the null hypothesis is rejected with a probability of error less than $5 \%$.

Table 21: Pseudo R squared for specific hypothesis 3

\begin{tabular}{|l|r|}
\hline \multicolumn{2}{|c|}{ Pseudo R squared } \\
\hline Cox and Snell &, 640 \\
\hline Nagelkerke &, 730 \\
\hline McFadden &, 487 \\
\hline
\end{tabular}

Table 21 presents favorable pseudo $\mathrm{R}$ squared values, which ensures an adequate fit of the proposed model to explain skills in electronics and digital circuits. Likewise, the learning strategies is the variable that most affects the Arduino hardware of the explained variable with a value of Wald $=6.568$ and $p=.010<0.05$ (Table 22).

Table 22: Parameter estimates of the general hypothesis 4

\begin{tabular}{|l|c|c|c|c|c|}
\hline & & & & \multicolumn{2}{|c|}{$\begin{array}{c}\mathbf{9 5 \%} \text { interval } \\
\text { trustworthy }\end{array}$} \\
\cline { 5 - 6 } & Estimate & S.I.G & Wald & Min & Max \\
\hline $\begin{array}{l}\text { [V3D3_arduino hardware } \\
\text { for electronic and digital } \\
\text { circuits=1] }\end{array}$ & $-8,390$ &, 001 & 11,715 & $-13,194$ & $-3,585$ \\
\hline $\begin{array}{l}\text { [V3D3_arduino hardware } \\
\text { for electronic and digital } \\
\text { circuits = 2] }\end{array}$ & -5.083 & .015 & 5,924 & $-9,176$ &,- 990 \\
\hline $\begin{array}{l}\text { [V1_Learning strategies }= \\
\text { 1] }\end{array}$ & $-4,173$ & .010 & 6,568 & $-7,365$ & -.982 \\
\hline $\begin{array}{l}\text { [V1_Learning strategies }= \\
\text { 2] }\end{array}$ & $-3,431$ & .046 & 3,996 & $-6,795$ & -.067 \\
\hline [V2_Academic Goals = 1] & $-3,142$ & .077 & 3,132 & $-6,621$ &, 337 \\
\hline [V2_Academic Goals = 2] & $-5,295$ & .020 & 5,439 & $-9,746$ &,- 845 \\
\hline
\end{tabular}

\subsection{Specific hypothesis test 4}

H1: There is no incidence between learning strategies and academic goals in arduino electronics software and digital circuits in a Private University Lima, 2020.

$\mathrm{H} 2$ : There is an incidence between learning strategies and academic goals in arduino electronics software and digital circuits in a Private University Lima, 2020.

Table 23: Model fit tests and likelihood ratio for specific hypothesis 4

\begin{tabular}{|l|r|r|r|r|}
\hline \multicolumn{5}{|c|}{ Model fit information } \\
\hline & $\begin{array}{l}\text { Logarithm of } \\
\text { probability -2 }\end{array}$ & Chi \\
Model & 187,849 & & & \\
\hline $\begin{array}{l}\text { Interception } \\
\text { only }\end{array}$ & & & & \\
\hline Final & 123,641 & 64,208 & 36 & S.I.G \\
\hline
\end{tabular}

Table 23 shows that the value $x 2=64.208,(p=.003<0.05)$, indicates that the proposed model serves to explain the behavior 
dependent on the variable competencies of electronic and digital circuits referred to Arduino software. In this sense, the null hypothesis is rejected with a probability of error less than $5 \%$.

Table 24: Pseudo R squared for specific hypotheses 4

\begin{tabular}{|l|r|}
\hline \multicolumn{2}{|c|}{ Pseudo R squared } \\
\hline Cox and Snell &, 514 \\
\hline Nagelkerke &, 574 \\
\hline McFadden &, 319 \\
\hline
\end{tabular}

Table 24 presents favorable pseudo $\mathrm{R}$ squared values, which ensures an adequate fit of the proposed model to explain skills in electronics and digital circuits. Likewise, learning strategies is the variable that most affects the Arduino software of the explained variable with a value of Wald $=9.624$ and $p=.023<0.05$ (Table 25).

Table 25: Parameter estimates for general hypothesis 4

\begin{tabular}{|l|r|r|r|r|r|}
\hline & & & & \multicolumn{2}{|c|}{$\begin{array}{c}\text { 95\% interval } \\
\text { trustworthy }\end{array}$} \\
\cline { 5 - 6 } & Estimate & S.I.G & Wald & \multicolumn{1}{c|}{ Min } & Max \\
\hline $\begin{array}{l}\text { [V3D4_arduino } \\
\text { software for electronic } \\
\text { and digital circuits=1] }\end{array}$ & -.186 &, 003 & 13,017 & $-2,951$ & 2,579 \\
\hline $\begin{array}{l}\text { [V3D4_arduino } \\
\text { software for electronic } \\
\text { and digital circuits=2] }\end{array}$ & -.453 &, 009 & 11,103 & -.225 & 2,319 \\
\hline $\begin{array}{l}\text { [V1_Learning } \\
\text { strategies=1] }\end{array}$ & $-3,556$ & .023 & 9,624 & $-6,797$ &,- 315 \\
\hline $\begin{array}{l}\text { [V1_Learning } \\
\text { strategies=2] }\end{array}$ & $-1,163$ & .048 & 8,580 & 4,156 & 1,830 \\
\hline [V2_Academic goals=1] & -.822 & .042 & 9,266 & 3,946 & 2,301 \\
\hline [V2_Academic goals=2] &, 654 &, 051 & 7,184 & $-2,334$ & 3,643 \\
\hline
\end{tabular}

\section{Discussion}

With reference to the general objective set, satisfactory values of $x 2=83.782,(p=.000<0.05)$, McFadden of 0.272 , Nagelkerke of $63 \%$, Cox and Snell of $61 \%$ and a Wald value of 16.326 were obtained. Indicating that the estimated model serves to explain the behavior of the dependent variable, being an adequate model, evidencing the rejection of the null hypothesis and admitting the incidence of learning strategies and academic goals in relation to the variable electronic competences and digital circuits. By virtue of this, they reaffirm the results obtained from the electronic and digital circuits competences with a tendency to be achieved with less than $70 \%$ of the engineering students of a Private University of Lima, 2020. In addition, The arduino software was estimated with more than $11 \%$ of the analyzed students presented low outstanding results compared to the other dimensions, which shows a profile of the student with deficiency in being able to develop skills in the description of a structure of the arduino software in the sktech. IDE, analysis of the arduino software instructions and achieve serial communication by connecting electronic devices to the arduino board, based on the data collected from the instrument application. On the other hand, the learning strategies show a moderate trend with more than $50 \%$ of the students, and it was evidenced that the support learning strategy presented the best results with a high level of more than $24 \%$ of the students compared to the rest of your group, according to the Roman y Gallego ACRA test instrument (see appendix) applied. Likewise, the academic goals presented a moderate trend concentrating more than $60 \%$ of the students, being the achievement goal the one that presented the best results with more than $30 \%$ in the high level compared to the others in their group, according to the respondents to the the Durán CMA Test.

Similarly, the dependent variable of the research presented an incidence of $63 \%$ of variability with respect to the explanatory variables in students, which means that learning strategies and academic goals are important so that higher-level students can optimally develop your skills in electronics and digital. circuits for their good academic performance in a comprehensive and professional manner, in that sense they can successfully face the demands of the labor market, it should also be noted that the value of Wald showed that learning strategies have a greater explanatory force of incidence, so that these guide to a better development of the electronic and digital circuit competencies of the students compared to the academic goals, in addition,

With reference to the specific objectives, it was admitted that there is an incidence between learning strategies and academic goals in basic electronics, arduino hardware and software electrical circuits and arduino electronics digital circuits in Engineering students, Universidad Privada de Lima, 2020. No however, for basic electronics, in comparison with the other dimensions, satisfactory inferential values of x2 $=61.281,(p=.005<0.05)$, Nagelkerke of $55.7 \%$ and Wald of 21.485 were obtained. This means that the learning strategies have a greater explanatory force of incidence for the basic electronic dimension compared to the other dimensions.

\section{Conclusions}

It was evidenced that the strategies of learning and academic goals affect the competences of electronic and digital circuits in engineering students, Universidad Privada Lima 2020. Due to acceptable values it was found of $x 2=83.782,(p=.000<0.05)$ and Wald $=16.326$ showing that the proposed model is plausible.

It was verified that the strategies of learning and academic goals affect basic electronics and digital circuits in Engineering students, Private University, 2020. Due to the favorable values obtained of $\mathrm{x} 2=61.281,(\mathrm{p}=.005<0.05)$ and Wald $=21.485$, which indicates that the proposed model is acceptable.

It was found that learning strategies and academic goals affect the electrical components of electronics and digital circuits in Engineering students, Private University, 2020. By favorable values of $\mathrm{x} 2=53.136,(\mathrm{p}=.033<0.05)$ and Wald $=16.073$, indicating that the proposed model is acceptable.

It was shown that the strategies of learning and academic objectives affect the hardware of Arduino electronics and digital circuits in Engineering students, Private University, 2020. Due to the value obtained from $\mathrm{x} 2=90.897,(\mathrm{p}=.000<0.05)$ and Wald $=6.568$, it which indicates that the proposed model is acceptable.

It is finally concluded that learning strategies and academic goals affect arduino electronics and digital circuits software in Engineering students, Private University, 2020. Due to the 
acquired value of $\mathrm{x} 2=64.208,(\mathrm{p}=.003<0.05)$ and Wald $=9.624$, indicating that the proposed model is acceptable.

It was considered that there is an option that allows to dynamically cover a large volume of data, as well as flexible for educational environments, known as educational data mining $[20]$.

\section{Recommendations}

It is recommended that the academic directors of the Private University establish institutional guidelines in their curricular plans for the implementation, incorporation and application of learning strategies and academic goals so that engineering students can effectively develop electronic and digital circuit skills, having significant learning.

The academic coordinator of engineering of the Private University is suggested to carry out activity programs for students of electronics and digital circuits in which topics of learning strategies and academic goals are developed in such a way that they can apply it in the subject and help them to develop. your core competencies in electronics, electrical components, arduino software, and arduino hardware.

It is proposed that the engineering professors of the Private University encourage their students of electronics and digital circuits in their pedagogical practices to use learning strategies, such as the acquisition, coding, retrieval and support of information, in the sense of raising skills and learning from the subject and achieve their academic goals.

New methods are recommended to better cover teaching strategies and thus avoid possible dropouts that may motivate students to drop out of college, such as an educational data mining option [21].

\section{References}

[1] British Council, "The reform of the peruvian university system: internationalisation, progress, challenges and opportunities," 1-123, 2016.

[2] Perú. Sistema Nacional de Evaluación Acreditación y Certificación de la Calidad Educativa, Resolución № 022-2016-SINEACE/CDAH-P. Modelo de Acreditación para Programas de Estudios de Educación Superior Universitaria, 2016.

[3] OCDE, "Estrategia de competencias de la OCDE Reporte Diagnostico: Peru 2016," Organizacion Para La Cooperacion y El Desarrollo Economico, $182,2016$.

[4] M. Huerta Rosales, R. Penadillo Lirio, M. Kaqui Valenzuela, "Construcción del currículo universitario con enfoque por competencias. Una experiencia participativa de 24 carreras profesionales de la UNASAM," Revista Iberoamericana de Educación, 74, 83-106, 2017, doi:10.35362/rie740609.

[5] F. Guzmán Marín, "Problemática general de la educación por competencias," Revista Iberoamericana de Educación, 74, 107-120, 2017, doi:10.35362/rie740610.

[6] M.E. Bello van der Ree, J.A. Morales Lozano, "Competencias claves de los estudiantes universitarios para el uso de las TIC," Revista de Comunicación de La SEECI, 50, 43-72, 2019, doi:10.15198/seeci.2019.50.43-72.

[7] J.J. Aiquipa, C.M. Ramos, R. Curay, L.L. Guizado, "Factores implicados para realizar o no realizar tesis en estudiantes de psicología," Propósitos y Representaciones, 6(1), 21-82, 2017, doi:10.20511/pyr2018.v6n1.180.

[8] A.F. Hoffman, R. Ledesma, M.F. Liporace, "Estilos y estrategias de aprendizaje en estudiantes universitarios de Buenos Aires," Revista de Psicologia (Peru), 35(2), 535-573, 2017, doi:10.18800/psico.201702.006.

[9] P. Guía, C. Exequel, P. Villalobos, Metas académicas, estilos atributivos y estrategias de aprendizaje en estudiantes secundarios de establecimientos vulnerables de la Región del BioBío, Universidad de Concepción. Facultad de Ciencias Sociales. Departamento de Psicología, 2017.

[10] M. Acevedo Zuluaga, Correlación entre Hábitos de Estudio, Estrategias de Aprendizaje y Rendimiento Académico, en Estudiantes de Fonoaudiología de la Corporación Universitaria Iberoamericana, 2016.

[11] A. Carlos, A.Q. Condezo, U N I V E R S I D A D N A C I O N A L D E E D U C A C I Ó N E n r i q u e G u z m á n y V a 11 e Alma Máter del Magisterio Nacional ESCUELA DE POSGRADO Ulises Abdon PISCOYA SILVA, Universidad Nacional de Educación Enrique Guzmán y Valle. Escuela de Posgrado., 2018.

[12] C.M. Diez Canseco Gómez, Metas del logro, clima de apoyo a la autonomía, estrategias metacognitivas de aprendizaje y desorganización en estudiantes de psicología de una universidad privada de Lima Metropolitana, Universidad de Lima, 2016, doi:10.26439/ulima.tesis/3233.

[13] F. De Educación, U. De Posgrado, M. Faustina, F. Silva, UNIVERSIDAD NACIONAL MAYOR DE SAN MARCOS, Universidad Nacional Mayor de San Marcos, 2017.

[14] J.R. Martínez, F. Galán, "Estrategias de aprendizaje, motivación y rendimiento académico en alumnos universitarios," REOP - Revista Española de Orientación y Psicopedagogía, 11(19), 35, 2014, doi:10.5944/reop.vol.11.num.19.2000.11323.

[15] S. Nabizadeh, S. Hajian, Z. Sheikhan, F. Rafiei, "Prediction of academic achievement based on learning strategies and outcome expectations among medical students," BMC Medical Education, 19(1), 99, 2019, doi:10.1186/s12909-019-1527-9.

[16] M. Carles, C. Montserrat, M. Palma, C. Mercè, M. Pérez, "Estrategias de enseñanza y aprendizaje," Revista Docencia Universitaria, 9(1), 155-159, 2008

[17] E. Durán-Aponte, D. Arias-Gómez, "Validez del Cuestionario de Metas Académicas (CMA) en una muestra de estudiantes universitarios," Cuadernos Hispanoamericanos de Psicología, 15(1), 23-36, 2016, doi:10.18270/chps..v15i1.1776.

[18] P.R. Pintrich, The Role of Goal Orientation in Self-Regulated Learning, Elsevier: 451-502, 2000, doi:10.1016/b978-012109890-2/50043-3.

[19] Ingeniería Electrónica con mención en Telecomunicaciones $\mid \mathrm{UCH}$.

[20] P. Nuankaew, W. Nuankaew, K. Phanniphong, S. Imwut, S. Bussaman, "Students Model in Different Learning Styles of Academic Achievement at the University of Phayao, Thailand," International Journal of Emerging Technologies in Learning (IJET), 14(12), 133-157, 2019.

[21] P. Nuankaew, "Dropout Situation of Business Computer Students, University of Phayao," International Journal of Emerging Technologies in Learning (IJET), 14(19), 115-131, 2019. 


\section{Appendix}

\section{ACRA TEST:}

This test is divided into four scales: Acquisition of information: It helps the student to know how to acquire the necessary information for the study. Information coding: It informs about how the main and secondary ideas of a text should be differentiated. Information retrieval: It sets out the mechanisms necessary to retrieve previously stored information. Information support: What means and conditions will help improve the study.

Next, the student must take this test, which must be answered in the following way: The questions that are asked must be answered as follows:

If you NEVER or NEVER do what is asked, you must put A. If the question is EVER done, put $\mathrm{B}$.

If ENOUGH TIMES what is asked is done, put $\mathrm{C}$.

If you ALWAYS do what you ask, you have to put D.

\begin{tabular}{|c|c|c|c|c|}
\hline \multirow{2}{*}{$\begin{array}{l}\text { Scale I: Information Acquisition Strategy: } \\
\text { 1. Before starting to study I read the index, or the } \\
\text { summary, or the sections of the material to be } \\
\text { learned. }\end{array}$} & A & $\mathrm{B}$ & $\mathrm{C}$ & $\mathrm{D}$ \\
\hline & & & & \\
\hline $\begin{array}{l}\text { 2. When I am going to study a material, I write } \\
\text { down the important points that I have seen in a first } \\
\text { cursory reading to more easily get an overview. }\end{array}$ & & & & \\
\hline $\begin{array}{l}\text { 3. When I begin to study a lesson, I read it all over } \\
\text { the top first. }\end{array}$ & & & & \\
\hline $\begin{array}{l}\text { 4. As I study, I look for the meaning of unknown } \\
\text { words, or of which I have doubts about their } \\
\text { meaning. }\end{array}$ & & & & \\
\hline $\begin{array}{l}\text { 5. In books, notes or other material to learn, I } \\
\text { underline in each paragraph the words, data or } \\
\text { phrases that seem most important to me. }\end{array}$ & & & & \\
\hline $\begin{array}{l}\text { 6. I use signs (admirations, asterisks, drawings...), } \\
\text { some of them only intelligible by me, to highlight } \\
\text { those information in the texts that I consider } \\
\text { especially important. }\end{array}$ & & & & \\
\hline $\begin{array}{l}\text { 7. I use pencils or pens of different colors to } \\
\text { promote learning. }\end{array}$ & & & & \\
\hline 8. I use the underlining to facilitate memorization. & & & & \\
\hline $\begin{array}{l}\text { 9. To discover and highlight the different parts of } \\
\text { what is composes a long text, subdivided into } \\
\text { several small by means of annotations, titles and } \\
\text { epigraphs. }\end{array}$ & & & & \\
\hline $\begin{array}{l}\text { 10. I write down words or phrases by the author, } \\
\text { which seem significant to me, in the margins of } \\
\text { books, articles, notes, or on a separate page. }\end{array}$ & & & & \\
\hline $\begin{array}{l}\text { 11. During the study, I write or repeat the important } \\
\text { or most difficult data to remember several times. }\end{array}$ & & & & \\
\hline $\begin{array}{l}\text { 12. When the content of a topic is dense and } \\
\text { difficult I reread it slowly. }\end{array}$ & & & & \\
\hline $\begin{array}{l}\text { 13. I read aloud, more than once, the underlines, } \\
\text { diagrams, etc..., made during the study. }\end{array}$ & & & & \\
\hline $\begin{array}{l}\text { 14. I repeat the lesson as if I were explaining it to a } \\
\text { classmate who does not understand it. }\end{array}$ & & & & \\
\hline $\begin{array}{l}\text { 15. When I study I try to mentally summarize the } \\
\text { most important things. }\end{array}$ & & & & \\
\hline $\begin{array}{l}\text { 16. To check what I am learning about a topic, I ask } \\
\text { myself section by section. }\end{array}$ & & & & \\
\hline
\end{tabular}

17. Even if I don't have to take an exam, I usually think and reflect on what I've read, studied, or heard from teachers.

18. After analyzing a graphic or text drawing, I spend some time learning it and reproducing it without the book.

19. I make them ask me the underlines, diagrams, etc. facts when studying a topic.

20 . When I am studying a lesson, to facilitate understanding, I rest, and then I review it to learn it better.

Sum

\begin{tabular}{|l|l|l|l|l|}
\hline Multiply & $\mathrm{X} 1$ & $\mathrm{X} 2$ & $\mathrm{X} 3$ & $\mathrm{X} 4$ \\
\hline
\end{tabular}

Outcome

Direct Score

Percentile

Scale Ii: Information Coding Strategy:

1. When I study, I make drawings, figures, graphs or vignettes to represent the relationships between fundamental ideas.

2. To solve a problem, I begin by carefully recording the data and then try to represent it graphically.

3. When I read, I differentiate important or main aspects and contents from accessories or secondary ones.

4. I look for the "structure of the text", that is, the relationships already established between its contents.

5. I rearrange or carry out, from a personal point of view, new relationships between the ideas contained in a topic.

6. I relate or link the topic I am studying with others that I have studied or with the data or knowledge previously learned.

7. I apply what I learn in some subjects to better understand the contents of others.

8. I discuss, relate or compare with my colleagues the works, diagrams, summaries or topics that we have studied.

9. I go to friends, teachers or family when I have doubts about the study topics or to exchange information.

10. I complete the information in the textbook or class notes by going to other books, encyclopedias, articles, etc.

11. I establish relationships between the knowledge that the study provides me and the experiences, events or anecdotes of my private and social life.

12. I associate the information and data that I am learning with fantasies of my past or present life.

13. When studying, I put my imagination into play, trying to see, like in a movie, what the subject suggests to me.

14. I make comparisons by making metaphors with the issues I am learning (eg, the kidneys function as a filter).

15 . When the topics are very abstract, I try to look for something familiar (animal, plant, object or event) that resembles what I am learning.

16. I carry out exercises, tests or small experiments, etc., as an application of what I have learned.

17. I use what I learn, as much as possible, in my daily life.

18. I try to find possible social applications in the content I study.

19. I am interested in the application that the subjects I study may have to the labor fields that I know.

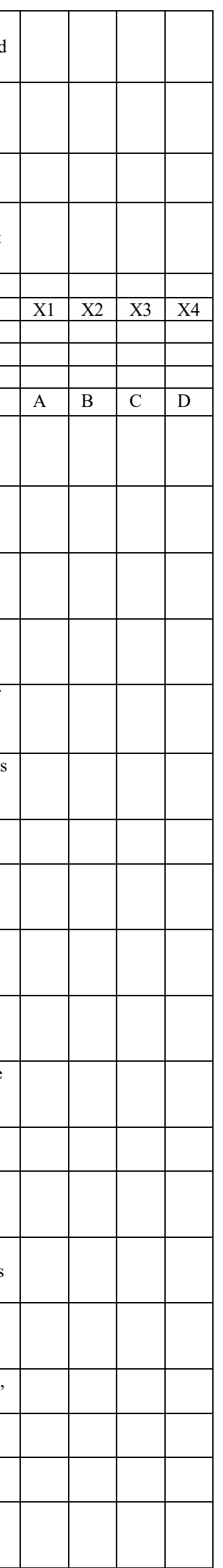




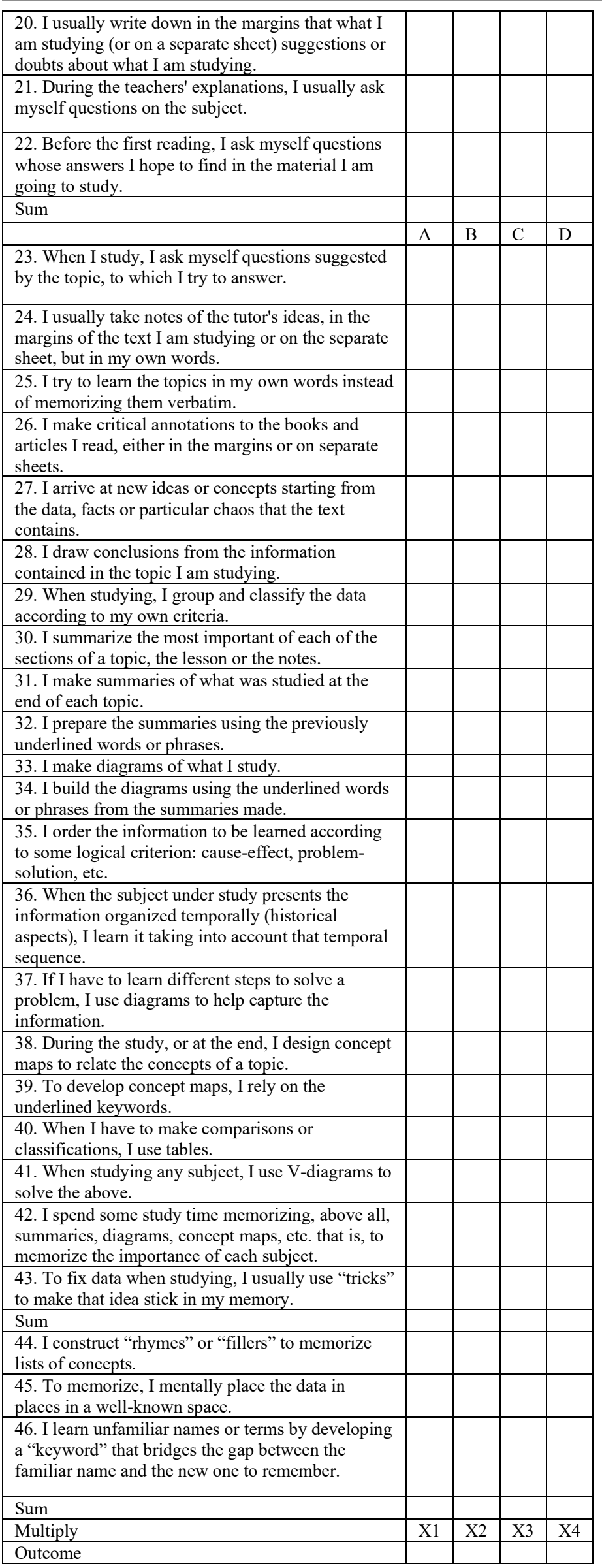

\begin{tabular}{|c|c|c|c|c|}
\hline \multicolumn{5}{|l|}{ Direct Score } \\
\hline Percentile & & & & \\
\hline Scale Iii: Information Recovery Strategy & $\mathrm{A}$ & $\mathrm{B}$ & $\mathrm{C}$ & $\mathrm{D}$ \\
\hline $\begin{array}{l}\text { 1. Before speaking or writing, I remember words } \\
\text { and drawings that are related to the "main ideas" of } \\
\text { the material studied. }\end{array}$ & & & & \\
\hline $\begin{array}{l}\text { 2. Before speaking or writing, I use keywords or } \\
\text { phrases that help me differentiate the main and } \\
\text { secondary ideas of what I study. }\end{array}$ & & & & \\
\hline $\begin{array}{l}\text { 3. When I have to present something orally or in } \\
\text { writing, I remember drawings, images, etc. through } \\
\text { which I elaborated the information during learning. }\end{array}$ & & & & \\
\hline $\begin{array}{l}\text { 4. Before responding to an exam, I remember those } \\
\text { groupings of concepts (summaries, diagrams, etc.) } \\
\text { made at the time of studying. }\end{array}$ & & & & \\
\hline $\begin{array}{l}\text { 5. For important questions, which are difficult for } \\
\text { me to remember, I look for secondary data in order } \\
\text { to be able to remember what is important. }\end{array}$ & & & & \\
\hline $\begin{array}{l}\text { 6. It helps me to remember what I have learned by } \\
\text { evoking events, episodes or clues that occurred } \\
\text { during class or at other learning moments. }\end{array}$ & & & & \\
\hline $\begin{array}{l}\text { 7. It helps me to remember other topics that are } \\
\text { related to what I really want to remember. }\end{array}$ & & & & \\
\hline $\begin{array}{l}\text { 8. Putting myself in a mental and affective situation } \\
\text { similar to that experienced during the teacher's } \\
\text { explanation or at the time of study, makes it easier } \\
\text { for me to remember important information. }\end{array}$ & & & & \\
\hline $\begin{array}{l}\text { 9. In order to better recover what I have learned, I } \\
\text { take into account the corrections and observations } \\
\text { that teachers make in exams, exercises or } \\
\text { assignments. }\end{array}$ & & & & \\
\hline $\begin{array}{l}\text { 10. To remember information, I first look for it in } \\
\text { my memory and then decide if it fits what I have } \\
\text { been asked or want to answer. }\end{array}$ & & & & \\
\hline $\begin{array}{l}\text { 11. Before I start to speak or write, I think and } \\
\text { mentally prepare what I am going to say or write. }\end{array}$ & & & & \\
\hline $\begin{array}{l}\text { 12. I try to express what I have learned in my own } \\
\text { words instead of repeating literally or verbatim } \\
\text { what the book or the teacher says. }\end{array}$ & & & & \\
\hline $\begin{array}{l}\text { 13. When answering an exam, before writing, first I } \\
\text { remember, in any order, everything I can, then I } \\
\text { order it and make an outline or script and finally } \\
\text { develop it point by point. }\end{array}$ & & & & \\
\hline $\begin{array}{l}\text { 14. When I have to do a free writing on any subject, } \\
\text { I write down the ideas that occur to me, then I order } \\
\text { them and finally I write them. }\end{array}$ & & & & \\
\hline $\begin{array}{l}\text { 15. When carrying out an exercise or exam, I am } \\
\text { concerned about its presentation, order, cleanliness, } \\
\text { margins. }\end{array}$ & & & & \\
\hline $\begin{array}{l}\text { 16. Before doing a written assignment, I make an } \\
\text { outline, script or program of the points to be } \\
\text { discussed. }\end{array}$ & & & & \\
\hline Sum & & & & \\
\hline & $\mathrm{A}$ & $\mathrm{B}$ & $\mathrm{C}$ & $\mathrm{D}$ \\
\hline $\begin{array}{l}\text { 17. When faced with a problem or difficulty, I first } \\
\text { consider the data that I know before venturing to } \\
\text { provide an intuitive solution. }\end{array}$ & & & & \\
\hline $\begin{array}{l}\text { 18. When I have to answer a topic for which I have } \\
\text { no data, I generate an "approximate" answer } \\
\text { relating what I already know about other topics. }\end{array}$ & & & & \\
\hline Sum & & & & \\
\hline Multiply & $\mathrm{X} 1$ & $\mathrm{X} 2$ & $\mathrm{X} 3$ & $\mathrm{X} 4$ \\
\hline Outcome & & & & \\
\hline Direct Score & & & & \\
\hline Percentile & & & & \\
\hline Scale Iv: Processing Support Strategy & $\mathrm{A}$ & $\mathrm{B}$ & $\mathrm{C}$ & $\mathrm{D}$ \\
\hline $\begin{array}{l}\text { 1. Before speaking or writing, I remember words } \\
\text { and pictures that are related to the "main ideas" of } \\
\text { the material studied. }\end{array}$ & & & & \\
\hline $\begin{array}{l}\text { 2. Before speaking or writing, I use keywords or } \\
\text { catch phrases that help me differentiate the main } \\
\text { and secondary ideas of what I study. }\end{array}$ & & & & \\
\hline
\end{tabular}




\begin{tabular}{|c|c|c|c|c|}
\hline $\begin{array}{l}\text { 3. When I have to present something orally or in } \\
\text { writing, I remember drawings, images, etc. through } \\
\text { which I elaborated the information during learning. }\end{array}$ & & & & \\
\hline $\begin{array}{l}\text { 4. Before responding to an exam, I remember those } \\
\text { groupings of concepts (summaries, diagrams, etc.) } \\
\text { made at the time of studying. }\end{array}$ & & & & \\
\hline $\begin{array}{l}\text { 5. For important questions, which are difficult for } \\
\text { me to remember, I look for secondary data in order } \\
\text { to be able to remember what is important. }\end{array}$ & & & & \\
\hline $\begin{array}{l}\text { 6. It helps me to remember what I have learned by } \\
\text { evoking events, episodes or clues that occurred } \\
\text { during class or at other learning moments. }\end{array}$ & & & & \\
\hline $\begin{array}{l}\text { 7. It helps me to remember other topics that are } \\
\text { related to what I really want to remember. }\end{array}$ & & & & \\
\hline $\begin{array}{l}\text { 8. Putting myself in a mental and affective situation } \\
\text { similar to that experienced during the teacher's } \\
\text { explanation or at the time of study, makes it easier } \\
\text { for me to remember important information. }\end{array}$ & & & & \\
\hline $\begin{array}{l}\text { 9. In order to better recover what I have learned, I } \\
\text { take into account the corrections and observations } \\
\text { that teachers make in exams, exercises or } \\
\text { assignments. }\end{array}$ & & & & \\
\hline $\begin{array}{l}\text { 10. To remember information, I first look for it in } \\
\text { my memory and then decide if it fits what I have } \\
\text { been asked or want to answer. }\end{array}$ & & & & \\
\hline $\begin{array}{l}\text { 11. Before I start to speak or write, I think and } \\
\text { mentally prepare what I am going to say or write. }\end{array}$ & & & & \\
\hline $\begin{array}{l}\text { 12. I try to express what I have learned in my own } \\
\text { words instead of repeating literally or verbatim } \\
\text { what the book or the teacher says. }\end{array}$ & & & & \\
\hline $\begin{array}{l}\text { 13. When answering an exam, before writing, first I } \\
\text { remember, in any order, everything I can, then I } \\
\text { order it and make an outline or script and finally } \\
\text { develop it point by point. }\end{array}$ & & & & \\
\hline $\begin{array}{l}\text { 14. When I have to do a free writing on any subject, } \\
\text { I write down the ideas that occur to me, then I order } \\
\text { them and finally I write them. }\end{array}$ & & & & \\
\hline $\begin{array}{l}\text { 15. When carrying out an exercise or exam, I am } \\
\text { concerned about its presentation, order, cleanliness, } \\
\text { margins. }\end{array}$ & & & & \\
\hline $\begin{array}{l}\text { 16. Before doing a written assignment, I make an } \\
\text { outline, script or program of the points to be } \\
\text { discussed. }\end{array}$ & & & & \\
\hline $\begin{array}{l}\text { 17. When faced with a problem or difficulty, I first } \\
\text { consider the data that I know before venturing to } \\
\text { provide an intuitive solution. }\end{array}$ & & & & \\
\hline $\begin{array}{l}\text { 18. When I have to answer a topic for which I have } \\
\text { no data, I generate an "approximate" answer } \\
\text { relating what I already know about other topics. }\end{array}$ & & & & \\
\hline Sum & & & & \\
\hline & $\mathrm{A}$ & $\mathrm{B}$ & $\mathrm{C}$ & $\mathrm{D}$ \\
\hline $\begin{array}{l}\text { 18. I use personal resources to control my anxiety } \\
\text { states when they prevent me from concentrating on } \\
\text { the study. }\end{array}$ & & & & \\
\hline $\begin{array}{l}\text { 19. I imagine places, scenes or events in my life to } \\
\text { calm me down and to focus on work. }\end{array}$ & & & & \\
\hline $\begin{array}{l}\text { 20. I know how to self-relax, self-talk, self-apply } \\
\text { positive thoughts to be calm on exams. }\end{array}$ & & & & \\
\hline $\begin{array}{l}\text { 21. I tell myself that I can exceed my current } \\
\text { performance level (expectations) in the various } \\
\text { subjects. }\end{array}$ & & & & \\
\hline $\begin{array}{l}\text { 22. I try that in the place I study there is nothing } \\
\text { that can distract me, such as people, noise, disorder, } \\
\text { lack of light and ventilation, etc. }\end{array}$ & & & & \\
\hline $\begin{array}{l}\text { 23. When I have family conflicts, I try to resolve } \\
\text { them sooner, if I can, to better concentrate on } \\
\text { studying. }\end{array}$ & & & & \\
\hline $\begin{array}{l}\text { 24. If I am studying and am distracted by thoughts } \\
\text { or fantasies, I fight them by imagining the negative } \\
\text { effects of not having studied. }\end{array}$ & & & & \\
\hline $\begin{array}{l}\text { 25. At work, I am encouraged to exchange opinions } \\
\text { with my colleagues, friends or family about the } \\
\text { subjects I am studying. }\end{array}$ & & & & \\
\hline
\end{tabular}

26. I am satisfied that my colleagues, teachers and family value my work positively.

27. I avoid or resolve, through dialogue, conflicts that arise in personal relationships with colleagues, teachers or family members.

28. To improve myself it stimulates me to know the achievements or successes of my colleagues.

29 . I encourage and help my classmates to be as successful as possible in their homework.

30. I say words of encouragement to myself to stimulate and keep me on study assignments.

31. I study to expand my knowledge, to know more, to be more expert.

32. I make an effort in the studio to be proud of myself.

33. I seek to have prestige among my colleagues, friends and family, standing out in studies.

34. I study to get rewards in the short term and to achieve a comfortable social status in the future. 35. I make an effort to study to avoid negative consequences, such as reprimands, upsets or other unpleasant situations in the family, etc.

Sum

Multiply

Outcome

Direct Score

Percentile

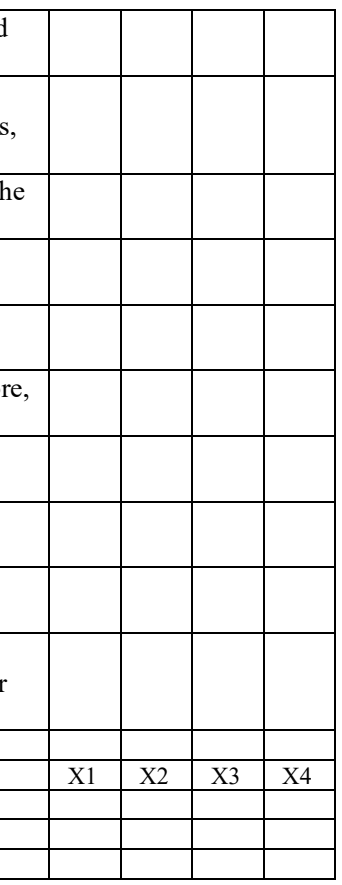

